\title{
The Politics of Childhood in Ellis's Three Wishes
}

\author{
Wafaa Hasan \\ McMaster University
}

Follow this and additional works at: https://docs.lib.purdue.edu/clcweb

Part of the Comparative Literature Commons, and the Critical and Cultural Studies Commons

Dedicated to the dissemination of scholarly and professional information, Purdue University Press selects, develops, and distributes quality resources in several key subject areas for which its parent university is famous, including business, technology, health, veterinary medicine, and other selected disciplines in the humanities and sciences.

CLCWeb: Comparative Literature and Culture, the peer-reviewed, full-text, and open-access learned journal in the humanities and social sciences, publishes new scholarship following tenets of the discipline of comparative literature and the field of cultural studies designated as "comparative cultural studies." Publications in the journal are indexed in the Annual Bibliography of English Language and Literature (Chadwyck-Healey), the Arts and Humanities Citation Index (Thomson Reuters ISI), the Humanities Index (Wilson), Humanities International Complete (EBSCO), the International Bibliography of the Modern Language Association of America, and Scopus (Elsevier). The journal is affiliated with the Purdue University Press monograph series of Books in Comparative Cultural Studies. Contact: <clcweb@purdue.edu>

\section{Recommended Citation}

Hasan, Wafaa. "The Politics of Childhood in Ellis's Three Wishes." CLCWeb: Comparative Literature and Culture 10.2 (2008): <https://doi.org/10.7771/1481-4374.1350>

This text has been double-blind peer reviewed by $2+1$ experts in the field.

The above text, published by Purdue University Press (CPurdue University, has been downloaded 1388 times as of 11/ $07 / 19$.

This document has been made available through Purdue e-Pubs, a service of the Purdue University Libraries. Please contact epubs@purdue.edu for additional information.

This is an Open Access journal. This means that it uses a funding model that does not charge readers or their institutions for access. Readers may freely read, download, copy, distribute, print, search, or link to the full texts of articles. This journal is covered under the CC BY-NC-ND license. 


\section{PURDUE}

UNIVERSITY PRESS <http://www.thepress.purdue.edu>

\section{CLCWeb: Comparative Literature and Culture}

ISSN 1481-4374 <http://docs.lib.purdue.edu/clcweb> Purdue University Press (C)Purdue University

CLCWeb: Comparative Literature and Culture, the peer-reviewed, full-text, and open-access learned journal in the humanities and social sciences, publishes new scholarship following tenets of the discipline of comparative literature and the field of cultural studies designated as "comparative cultural studies." In addition to the publication of articles, the journal publishes review articles of scholarly books and publishes research material in its Library Series. Publications in the journal are indexed in the Annual Bibliography of English Language and Literature (Chadwyck-Healey), the Arts and Humanities Citation Index (Thomson Reuters ISI), the Humanities Index (Wilson), Humanities International Complete (EBSCO), the International Bibliography of the Modern Language Association of America, and Scopus (Elsevier). The journal is affiliated with the Purdue University Press monograph series of Books in Comparative Cultural Studies. Contact: <clcweb@purdue.edu>

\section{Volume 10 Issue 2 (June 2008) Article 4 \\ Wafaa Hasan, "The Politics of Childhood in Ellis's Three Wishes: Palestinian and Israeli Children Speak" \\ <http://docs.lib.purdue.edu/clcweb/vol10/iss2/4> \\ Contents of CLCWeb: Comparative Literature and Culture 10.2 (2008) \\ Thematic Issue Racialized Narratives for Children \\ Edited by C. Richard King and John Streamas \\ <http://docs.lib.purdue.edu/clcweb/vol10/iss2/>}

Abstract: In "The Politics of Childhood in Ellis's Three Wishes: Palestinian and Israeli Children Speak," Wafaa Hasan outlines the recent controversy in Canada over the restrictions that shape "children's literature." Using Neil Postman's and John Locke's conceptions of childhood, Hasan unpacks the ways in which Ellis's Three Wishes has threatened popular conceptions of childhood. Specifically, as her analysis shows, Ellis's work redefines the boundaries of children's fiction by heterogenizing childhood experience and by affording its readers -- limited but consequential -- authorial agency. Further, Hasan asserts that Three Wishes liberates the idea of childhood as a developmental stage of ignorance by revealing the ways in which the "child" is a subject position that is applicable to different age groups (particularly adults who are racially or politically marginalized) and is often characterized by subordination. In the end, Hasan's article serves as a response to the censorship Ellis's text endured in 2006, highlighting and questioning the fervent investment some Ontarian adults have had in securing the illusion of apolitical and innocent childhoods. 


\section{Wafaa HASAN}

\section{The Politics of Childhood in Ellis's Three Wishes: Palestinian and Israeli Children Speak}

The Toronto and York school boards as well as the Ontario Library Association in Canada have recently found themselves tackling major issues concerning censorship, children's literature, and childhood in general. Three Wishes: Palestinian and Israeli Children Speak (2004), a non-fiction text by Canadian author Deborah Ellis, was at the centre of controversy in February 2006 when the Canadian Jewish Congress put pressure on the Ontario Library Association and Ontario school boards to remove the book from their reading lists for Grades 4 to 6 . Three Wishes juxtaposes testimonies of Palestinian children (persons under the age of 18) with those of Israeli children (again, persons under the age of 18) and the chapters alternate respectively. The book contains short narrative interviews with JewishIsraeli, Christian-Palestinian, and Muslim-Palestinian youth ages 8 to 18 in the region variably called Israel and/or Palestine. The narratives in Three Wishes communicate the children's everyday desires and dreams as well as the impact of militarization on their lives. Further, the narratives reveal the everyday struggles around security checkpoints, ubiquitous weaponry, militarization, death, suicide, and uncertain futures.

In 2006, the Canadian Jewish Congress wrote to every school board in Ontario requesting that Three Wishes be removed from the Ontario Library Association's Silver Birch Award list of recommended reading and from contention for the annual award (a program to promote recreational reading in which children in grades 4 to 6 across the province vote for their favorite book) (see Atkinson <http://www.publishersweekly.com/article/CA6322518.html>). Bernie M. Farber, the Chief Executive Officer of the Canadian Jewish Congress (CJC) is quoted in the Globe and Mail that "It was the considered opinion of the Canadian Jewish Congress ... that Three Wishes is a book best read, in a school system, by children older than those targeted by the Silver Birch independent reading program, which promotes a list of books to children in Grades 4 to 6"; further, Farber asks that educators assess the material, "place it in an appropriate age group and provide teaching modules to help young people understand the complexity of Middle East politics" (<http://www.cjc.ca/template.php?action=oped\&Rec=160>). Canadian columnist Nathalie Atkinson explains in Publisher's Weekly that the CJC claims the "lack of historical and political context" makes the book "unsuitable for children in grades 4 to 6" (Atkinson <http://www.publishersweekly.com/article/CA6322518.html>). Consequently, the Toronto District School Board made Three Wishes "off-limits to children below grade 7, removing it from elementary library shelves" with the exception of children with parental permission to read it (Atkinson <http://www.publishersweekly.com/article/CA6322518.html>).

According to the Canadian Broadcasting Company News Online, "The Toronto and York school boards pulled the book from their reading programs. But the Ontario Library Association decided to keep the book on its Silver Birch reading program, which encourages children in Grades 4 to 6 to read independently" ("Author of Book Palestinian" <http://www.cbc.ca/arts/story/2006/03/23/threewishes-ellis.html>). Three Wishes was ultimately removed from elementary school library shelves and given limited access in a growing number of school districts in Ontario, where the issue of whether the book -- intended for ages 9-12 -- is age appropriate "exploded" (Atkinson <http://www.publishersweekly.com/article/CA6322518.html>). But what is the "political context" that Farber speaks of? How must the topics of war, death, and victimization be narrated? And, for what purposes? Just as the rhetoric in this controversy leaves notions of context and narration in question, so too does it manifest the porousness of categories like "children's literature" or "child" for that matter. And thus the questions I explore in this paper: what does it mean to be a child? What is appropriate children's literature? What is the purpose of censoring or mediating textual content? Should children be protected from confronting issues of war, death, and violence? 
What is at stake if we reveal the immanence and prevalence of death to our young? What is at stake if we burst the idea that children are always and already "innocent"? Who benefits from securing the child inside and outside the book? The example of the CJC's objection to Three Wishes illustrates that childhood is considered a phase in which one is not yet engaging with conflict. For the CJC, childhood is a state of development including an age boundary in which complex politics and issues of violence and death cannot and should not be engaged with. It is once children pass the twelve year mark that they suddenly become critically aware and can thus peruse the contents of war texts.

How arbitrary is this boundary and what are the purposes of hiding such things from children? I address this question by exploring how Three Wishes (re)configures the categorization of children's literature and "the child" in general leaving distinct and numerical age boundaries fruitless. I argue that Three Wishes problematizes the boundaries of children's fiction and therefore childhood by heterogenizing children's experiences (even within a single spatially and temporally limited context) and by abandoning moral editorializing. Three Wishes diversifies childhood such that the categorical criteria for "adult" leaks into childhood and destabilizes age-based boundaries of agency and critical thinking. This essay will illustrate how Three Wishes problematizes biologically deterministic (i.e., Lockean) understandings of childhood by illuminating how the category of "child" is often no more than a subject-position that is applicable to people of many ages in Israel and Palestine. Ultimately, Three Wishes unravels a monolithic understanding of childhood as a contained, universal and fixed phase of innocence and passivity. Finally, Three Wishes understands children as agential subjects because it affords readers authorial participation. Its lack of moral-of-the-story conclusions lends narrative authority to the child reader. Because the book is unique in these ways, I postulate that while the CJC's claims with regard to Three Wishes are convincing, most of them rest on problematic assumptions about childhood.

In her well-known work "The Case of Peter Pan: The Impossibility of Children's Fiction" Jacqueline Rose asserts that children's fiction rests on the false principle that there is a child who is merely there to be addressed and that speaking to "it" might be straightforward. Peter Pan, like other fairy tales such as many of the Disney stories, claim to represent the child; to speak to and for children; and addresses them "as a group which is knowable and exists for the book" (Rose 58). The allegation that children compose a group that is knowable, reifies their identities and denies the wide variety of ways they comprehend and receive cultural texts. While many theorists such as Rose argue that children in fact have a much more mutually formative relationship with discourse -- one that cannot be characterized as a simple and transparent transference of ideologies from text to child -- the idea of children as a knowable and passive entity has roots in dominant Western discourse on childhood. John Locke, for example, has had tremendous influence in reaffirming childhood as a temporal state of rapid and tenuous development, when he posed his well-known thesis that at birth the mind is a blank tablet (a tabula rasa) (Postman 57). Locke fashioned the child as a non-agential, non-critical subject, if a subject at all. Thus, the child was no longer perceived as a miniature adult (as in the Middle Ages); he/she now appears an "unformed" person who through "literacy, education, reason, self-control and shame may be made into a civilized adult" (Postman 59).

Whatever this process of behaviour formation, Locke claims that prior to this assimilation the child remains a naïve and passive absorber of external influences. The rhetoric of developmental psychology and science, in general, reinforce these myths of childhood innocence and malleability (see Castaneda's Figurations; on pedagogical literature see Ariès; see also Postman 46). That the child "wants nothing, desires nothing, and demands nothing, except perhaps its own innocence" (Jenkins 16) not only essentializes children by homogenizing their desires and limitations; this rhetoric imagines children as apolitical, non-critical and pre-agential. Thus, children can be "known" and speaking to them, through literature, is simple. These common ideologies assume that the adult can completely control and therefore mold the child's experiences, character and actions. This trajectory also assumes that conflict is not and should not be part of childhood. (Unfortunately) children face pain and violence 
quite often in almost all parts of the world. Adult illusions that childhood should be and is painless can work to posit childhood as the utopic binary against which the reality of adulthood is juxtaposed. This -- in my view a problematic matter -- takes the focus off of "fixing" the adult world and centers adult attention on the project of creating a utopic childhood. Adults (already fixed, formed, and unchangeable) occupy a place of determinacy against which the malleability of the child can be oppositional.

Is it within this binary relationship that childhood be necessarily apolitical in that it is denied narratives of war and politics? How long should a child body remain (often coercively) ignorant of death, politics and war? How does the discourse around the malleable tabula rasa become a scapegoat for keeping people, through various forms and intensities of censorship, uninformed of world issues (i.e., religion, death, imperialism, colonization, and conflict)? The tabula rasa theory has been used, indirectly, as a scapegoat in the Three Wishes controversy to liken the text to an instructional booklet on violence, hate, and war (instead of a text that reveals unbearable and uncomfortable childhood realities). What does this control of representations of children inside the book accomplish? Rose claims that if children's fiction builds an image of the child inside the book, it does so in order to secure the child who is outside the book (58). While the corpus of criticism of children's literature is expanding, the best book is consistently believed to be one that "secures the reader to its intent and can be absolutely sure of its effects" (Rose 59). Accordingly, children's literature does not generally produce what the "known" child wants; it tends to iterate what the adult desires -- even while that desire is "construing the child as the object of its speech" (Rose 59). So "good" children's literature guarantees a particular reception, often promotes adult hegemonic values and leaves no room for "error." It is worth noting that it takes a certain understanding of the child as a non-critical being to believe this transfer of ideologies can so easily occur. Moreover, the desire to secure the child outside the book manifests a fear of the child. If we believe that children cannot engage with discourse in a mutual relationship and that the child's mind is indeed a tabula rasa, then organizations can argue effectively and convincingly for the need to strictly guide that which children are exposed to.

Some individuals and organizations argue that children's literature ought to be texts of guidance and must promote a temporality of happiness and political ignorance. If it is not secured as such, an acute fear emerges. If, as mentioned earlier, adulthood does not have a utopic childhood against which it compares its ailments, would adult consciousness lose its definition as a more realistic phase? Would adulthood, then, see the achievement of happiness and therefore, existential questions, as part of a continual human experience (inclusive of adulthood)? The project of securing happy childhoods is an effective distraction from achieving contentment in adulthood. According to Rose, adult utopic desires for innocence and happiness become projected onto the child through children's texts as they become manifestations of adult desires rather than sites in which children can relay what childhood experiences accurately entail. Now that I have outlined the ways in which an influential intellectual tradition has evoked the utter pliability as well as the knowability of children's identities, I situate Ellis's Three Wishes within Rose's theoretical premises (conscious of the fact that Three Wishes is nonfiction). Three Wishes de-essentializes this usually known and collectivized group of people we call children. It exposes a wide variety of children's experiences and manifests their heterogeneity even within one geographical space as is evidenced in the passages below. Moreover, the text opens itself up to diverse receptions and therefore destabilizes any possibility of a stable narration. No testimony is valorized over another through value-laden commentary or the hierarchical organization of stories. The speaking child, then, is not a universal one -- nor in this context of military conflict and occupation is the child depicted as helpless victim, for example.

Salam, a twelve-year-old Palestinian boy explains, "I don't want you to take my picture. Someone put my picture in a big American magazine. I was crying at the time, and I don't like it that everybody in America can see me crying. So don't take my picture" (103). Salam is acutely resistant to being defined by victimization. He not only asks for agency, he exercises it, demanding to be understood and represented in the way he wants. Other Palestinian children like Micheal (eleven-years-old) wish 
for peace and "don't know very much about the war" (37). Still others voice their desires to kill Israeli soldiers, oppose parents' wishes and evade checkpoints by sneaking through mountains $(82,85,94)$. Additional testimonies reveal some children's eagerness to kill suicide bombers and "terrorists" while they are eagerly anticipating Israeli conscription (76). Some run from soldiers to reach forbidden destinations (69) and participate in, as well as organize, youth groups that promote solidarity amongst various collectives (105). As such, Ellis presents a wide array of responses to a geographically and spatially limited context. Moreover, the book demonstrates that children are clearly not extraneous to political processes. Most Palestinian children, in fact, participate openly in political resistance against the occupation of the West Bank and Gaza and many Israeli children are aware of the political discourse surrounding their purportedly "security-burdened" Israel. Furthermore, the children make decisions and engage critically with social discourse. For example, Gul, a twelve-year-old Israeli boy, describes his values and resists the claim that he can be easily influenced. It is a powerful moment in which the "child" critiques his world, assesses consequences and advances an opinion that is not easily malleable. He says,

I don't like it that I will have to join the army in a few years but I don't have a choice ... sometimes the army goes into Palestinian cities ... they take Palestinians out of their homes, then bulldoze the homes so there is nothing left ... The soldiers might have to be rough to get Palestinians out of their house, because they won't want to leave. It's their home and they want to stay there. My mother doesn't want me being rough and mean to people when I'm a soldier ... She thinks going into the army will change the kind of person I am ... I don't see how that can happen. I am who I am. How can anything change that? (53; my emphasis)

Gul illustrates implicitly that children can engage with and within discourse and do not simply absorb discourse passively. While dominant Israeli masculinist discourse dictates that Israeli Defense Force (IDF) service leads to manliness, Gul questions this rhetoric and critically engages it. Gul's narrative subsequently problematizes Lockean (linear) models of child development. I am not arguing that Gul, for example, has an inherent personality that exists outside of discourse or social learning. The assumption of an inherent personality would verge on a different kind of biological determinism. Instead, I want to emphasize that Gul has and performs the ability, even as a child, to negotiate with and through discourse (both his mother's and Israel's). Within Locke's model of the tabula rasa Israeli nationalist and military discourse, for example, would be adopted by an "innocent" child transparently. The absence of the dialogical relationship between child and discourse in Lockean models of childhood development is stark.

In short, Three Wishes reveals differences in childhood experiences within both the Palestinian and Israeli sides and children's thoughts and actions are represented in complex ways. We cannot, then, reduce the stories in this book to a definition of what childhood is in Palestine, Israel, or the world. Moreover, readers cannot construe that children enduring military conflicts are all victims (nor can readers assume they are all implicated in the conflict). Some children are shown to absorb hegemonic ideals while others critique their parents' values or the law in their respective regions. The children's reactions and actions are just as varied as those of adults. Readers are, consequently, encouraged to individualize each child and the attempt to name or describe the universalized or abstract child as a knowable entity becomes impossible. Significantly, Three Wishes' intent is elusive. The book does not aim to secure the reader to its intent and cannot be sure of its effects and reception. Three Wishes' children speak of political resistance, murder, and poverty. Thus the content appears intimidating in the face of the conventional "security" of children's texts. Moreover, in my view, there is no perceptible overall theme or value that is being heightened over others. While Ellis includes facts and information about the Israeli/Palestinian conflict, she does not narrate the text in the sense of providing closure or authorial judgment to the children's testimonies. Ellis never comments on the stories themselves and ends the book with a child's voice: Mai's. The message is hardly one of "killing is bad," "let's save all the children," or "children are all peaceful and innocent." 
I want to emphasize that an examination of Ellis's involvement, as author and editor in transcribing and translating the testimonies I am describing into coherent English prose is warranted. Rose, for example, argues that children's literature is "impossible" because it sets up a world in which the adult comes first (author, maker, giver) and the child comes after (reader, product, receiver) but neither of the two enters the space in between (58). Although Three Wishes seems to present truthful and authentic accounts of children's experiences, the book cannot deny the adult and cultural mediation it employs. Thus, the text has not wholly entered the liminal space in between adult "making" and child "receiving" and the book has not transgressed the limits of children's fiction as posed by Rose. Ellis's methodology, intent, and the degree to which she has manipulated the text is not an issue I aim to examine here. Instead, I highlight how this text and its themes (or the lack of them) leave moral lessons loose. In " Disdain or Ignorance? Literary Theory and the Absence of Children's Literature" Deborah Thacker outlines the paradigms of reader-response theory in an effort to chart how child readers have been seen as (in)active textual/authorial participants. Thacker argues that modern picture books, for example, invite a child to share in the "telling." The child may finish the rhyme, lift the flap, fill in the word, or participate in the narrative to "tell" the pictures (7). The reader can perform the role of author and manipulate and even create meaning.

Similarly, children find room for authorial development in Three Wishes because they are offered the opportunity to make sense of conflicting and antagonistic testimonies. The chapters are short and can be read out of order -- there is no narrative or plot-like linearity in the progression of the pages. Furthermore, Ellis's presence does not, in any obvious way shape how these accounts of death, suicide, lack of mobility, claustrophobia, illness, murder, disease, anger, and poverty will be received. The child, therefore, becomes co-author and the effect of the book hardly predictable. That Three Wishes complicates the homogeneity of the category of child and that it leaves moral endings loose, I postulate, is what has people and organizations like the CJC intimidated. Even more pertinent and subversive is the way that Three Wishes problematizes childhood as a biological or developmental category and instead, defines it as a discursive classification contingent upon power structures. Childhood in Three Wishes is linked, not with a state of brain or corporeal development (i.e., biological immaturity), but with a subject position characterized by powerlessness. The child presented in this book becomes a fluid subject position that can be applied to many ages. For instance, Three Wishes' Palestinian stories demonstrate that Palestinian adults are often infantilized. For example Hakim, age 12, is a boy who after throwing rocks at Israeli soldiers, was shot in the legs fifteen times. He now has pins in his legs and talks about being completely bedridden. He says, "I can't move or go anywhere. If the soldiers come to look for me here, I will not be able to run away from them. My father is here, but he will not be able to protect me" (84). Hakim understands his father has no more social agency or institutional power than he does.

The existence of adulthood is contingent upon institutionally implemented privileges and rites-ofpassage. Postman contends in his The Disappearance of Childhood that the emergence of the "child" enjoyed a simultaneous emergence of the modern nuclear family structure and a strict separation of education and work. As the "form of childhood took shape, the form of the modern family took shape" and the essential event, as Ariès argues, was the invention and then extension of formal schooling (69). Mandatory formal schooling was a notable change, considering that prior to this time children were seen exclusively as slaves to their parents' debts and as workers (see, e.g., Adams, Berg, Berger, Duane, Neil, Ollendorff 158). Accordingly, the pattern of a child's life in relation to education and work was firmly set. Education was one thing; work another. Thus educational provisions increased throughout the twentieth century and children were taken further and further out of the adult world. With the emergence of the institutionalized school system (inspired by the printing press and mass literacy) adults were to be at work and children at school. A clear binary separation was instilled between child and adult and without these institutional signifiers of development it would not be viable 
to strictly define who was adult and who child. In other words, the modern family structure, and each member's role as worker/student, supported the existence of "childhood."

As the stories in Three Wishes illustrate, many Palestinian families have been and are being separated by checkpoints and walls (see, e.g., Maryam's story, 69) and thus their family structure and the roles within those structures are destabilized. Even if the family manages to stay together, their roles as workers and students are compromised under the circumstances of round-the-clock curfews, when students cannot attend school, and when workers are forced to miss work. While in Western discourse children are often offered the subject position of protectee -- and we see this performed by the community of adults in the CJC -- Hakim's story and narrative suggests that there is no prerogative or authority in (Palestinian) adulthood: "I am not afraid of [Israeli soldiers] ... the other boys and I, we take care of each other. When someone gets hurt, we all help to carry them off the street, the way they carried me" (84). For Hakim, there is no evidence of security provided by a community of adults or any social power they might summon up. The child, Hakim, is on his own and seeks support in a community of other children. As the narratives in Three Wishes suggest, Palestinian childhood, in the end, does not really exist. Hakim understands that only some children matter, so to speak. He notes the classed-nature of childhood: "I don't know any Israelis. I don't want to know any. They are not the same as me. The grown-ups value their own children but they think everyone else's children have no value" (85).

Hakim makes a profound statement about which bodies matter -- in this case it is the White body against which the Arab body is juxtaposed. Furthermore, childhood cannot exist within a marginalized people because the marginalized adult (like the colonized or the racialized) is often infantilized him or herself. As Jo-Ann Wallace contends, "the 'child' has never been a subject position available to all, or even most, children; moreover, it has been a subject-position imposed on colonized adults" (286). In fact, the word "child" was and is frequently used to describe adults who cannot read, adults who are regarded as intellectually childish (Wallace 42). Delineating between adulthood and childhood within a colonized or occupied group of people requires new definitions which do not rely on the work-school divide. In asserting that only some bodies have access to childhood I do not mean to valorize the preservation of conventional childhood because of the sometimes oppressive effects "childhood," as a discursive category, can have on children. For example, children in the West have little agency in making decisions about their custody, politics, body art, schooling and so on (see Megyery). Nevertheless I highlight that this subject position, which in some ways has become globalized discursively, is clearly only a subject position that certain children can assume and experience. In fact, it is a subjectivity that very little children (including some in the West can assume). Therefore advocating childhood is beside the point. Instead, I ask, what is the Canadian investment in this illusion and why do we impose it?

Based on the postulate that Ellis's text renders the taxonomy of children's literature porous and unfixed and that it reveals the idea of childhood as resting upon institutional mediation to exist, the argument that Three Wishes is unsuitable for children becomes convincing. This is a text that emerges as shaky, unsafe, unpredictable, and full of contradictions. It unravels the idea of childhood as a naturally and universally blissful developmental stage. The Western child cannot be secured from understanding its subjectivity as a product of politics and legal discourse. The claim that the child must be secured from particular topics and that children's literature need be more definitive and limited based on an assumption that childhood should be (and already is) a site of ignorance and purity. However, the children represented and "speaking" in Three Wishes are indeed children. The CJC is invested in a Western notion of childhood innocence that many of the children of the globe, like the child soldiers in Sierra Leone and Congo and the child prostitutes in Asia, have no chance of experiencing. The Western illusion of the child is not one that should be imposed on the globe rather. It is a precious illusion of a very small portion of the world, and Ellis's text clearly wants to challenge the assumptions upon which this illusion is based. In fact, that small portion of the world is hardly one of childhood inno- 
cence. Children in North America (i.e., Canada and the U.S.) have declared their ability to relate to this text and have therefore nominated it for the Silver Birch award.

In conclusion, I postulate that the removal of Three Wishes from reading lists in libraries and school boards was a practice of sheltering the privileged from the underprivileged and therefore depoliticizing the child subject. What does this mean? Could it be that people are only allowed to be introduced to such politically-charged issues once they have been "processed" through the institutional school system which (more recently with the corporatization of the educational system) does more to create conformists than to raise philosophical questions and foster critical thinking? Could it be that the said investment in the purity of childhood rests upon adult desires to preserve happiness in a temporal arena? What is it about hiding the political struggles of some children to other children that terrifies Western hegemonic institutions? Could it be the fear of a politicization of youth? It is important to question the deliberate masking of the victimization of others. Three Wishes generates criticism of childhood as a developmental category, one that everyone experiences "naturally" (as if it is a stage in development when one is completely, and blissfully, ignorant); it points out that children's, like adult's, engagement with discourse is dynamic and fluid; and it de-essentializes a group that is often feared and oppressed. Ultimately, Three Wishes reveals issues of childhood agency and power that scholarship generally struggles with. The controversy surrounding Three Wishes has bridged scholarly discussions about childhood agency with that of popular dinnertime rhetoric. Ultimately, this controversy leads to a simple conclusion: to shelter one child's story from another child's in an effort to preserve childhood is to reveal the suspiciousness and tenuousness of such categories.

\section{Works Cited}

Adams, Paul, Leila Berg, Nan Berger, Michael Duane, A.S. Neil, and Robert Ollendorff. Children's Rights: Towards the Liberation of the Child. London: Elek Books, 1971.

Ariès, Phillippe. Centuries of Childhood: A Social History of Family Life. Trans. Robert Baldrick. New York: Vintage, 1962.

Atkinson, Nathalie. "A Continuing Controversy." Publisher's Weekly (4 June 2006): <http://www.publishersweekly.com/article/CA6322518.html>.

"Author of Book on Palestinian, Israeli Children Speaks out." CBCnews.ca (23 March 2006): <http://www.cbc.ca/arts/story/2006/03/23/threewishes-ellis.html>.

Castaneda, Claudia. Figurations: Child, Bodies, Worlds. Durham: Duke UP, 2002.

Ellis, Deborah. Three Wishes: Palestinian and Israeli Children Speak. Toronto: Groundwood, 2004.

Farber, Bernie M. "Putting Books in the Right Hands." Canadian Jewish Congress: The Jewish Community's Official Voice on Public Affairs (23 March 2006): <http://www.cjc.ca/template.php?action=oped\&Rec=160>.

Jenkins, Henry. "Introduction: Childhood Innocence and Other Modern Myths." The Children's Culture Reader. Ed. Henry Jenkins. New York: New York UP, 1998. 1-36.

Megyery, Kathy, ed. Youth in Canadian Politics: Participation and Involvement. Toronto: Dundurn, 1991.

Postman, Neil. The Disappearance of Childhood. New York: Vintage, 1994.

Rose, Jacqueline S. "The Case of Peter Pan, The Impossibility of Children's Fiction." The Children's Culture Reader. Ed. Henry Jenkins. New York: New York UP, 1998. 58-66.

Thacker, Deborah. "Disdain or Ignorance? Literary Theory and the Absence of Children's Literature." The Lion and the Unicorn 24.1 (2001): 1-17.

Wallace, Jo-Ann. "Technologies of 'the Child': Towards a Theory of the Child-subject." Textual Practice 9.2 (1995): 285-302.

Author's profile: Wafaa Hasan works towards her Ph.D. in English and Cultural Studies at McMaster University with a dissertation entitled Historical Perceptions of Transnational Feminism in Palestine. Hasan's areas of specialization include the dynamics of gender-based activism in the West Bank, Gaza, and Israel, "third world feminisms," postcolonial theory, and race studies. Hasan is associate director of the Canada Research Chair Symposium for Diversity in Canadian Literary Cultures. E-mail: <hasanw@mcmaster.ca>. 